\title{
Effect of concentration and exposure period to butyrolactone I on meiosis progression in bovine oocytes
}

\author{
[Efeito de concentração e tempo de exposição à butirolactona I na progressão da meiose de oócitos bovinos]

$$
\text { P.R. Adona }{ }^{1,3} \text {, C.L.V. Leal }{ }^{2} *
$$ \\ ${ }^{1}$ Universidade Estadual Norte Fluminense - Campos dos Goytacazes, RJ \\ ${ }^{2}$ Faculdade de Zootecnia e Engenharia de Alimentos - USP \\ Av. Duque de Caxias - Norte, 225 \\ 13635-900 - Pirassununga, SP \\ ${ }^{3}$ Bolsista da CAPES
}

\begin{abstract}
The effect of concentration and exposure period of bovine oocytes to butyrolactone I (BLI) on meiotic block and in vitro maturation (IVM) kinetics was studied. In experiment 1 , all oocytes were at germinal vesicle stage $(\mathrm{GV})$, after $6 \mathrm{~h}$ in culture with 0,50 and $100 \mu \mathrm{M}$ BLI. After $12 \mathrm{~h}$, all oocytes cultured with 50 and $100 \mu \mathrm{M}$ BLI remained in GV. After $24 \mathrm{~h}$, less oocytes were in GV with $50 \mu \mathrm{M}(82 \%)$ than with $100 \mu \mathrm{M}$ BLI (99\%, $\mathrm{P}<0.05)$. In experiment 2, after 6h IVM, 93\% of control oocytes (IVM only) were in GV, while treated oocytes $(100 \mu \mathrm{M}$ BLI for 6,12 or $24 \mathrm{~h}$ prior to IVM) showed less oocytes in GV with increased exposure period to BLI prior to IVM $(83$ and $73 \%$, for $6 \mathrm{~h}$ and $12 \mathrm{~h}, \mathrm{P}<0.05)$. For a $24 \mathrm{~h}$ inhibition, $\mathrm{GV}$ rates were similar to $12 \mathrm{~h}(70 \%, \mathrm{P}>0.05)$. After $18 \mathrm{~h}$ IVM, metaphase II (MII) rates were similar for all groups (76-81\%). In experiment 3, after $6 \mathrm{~h}$ IVM, 74\% of treated oocytes (50 or $100 \mu \mathrm{M}$ $\mathrm{BLI}$ for $12 \mathrm{~h})$ were in $\mathrm{GV}$. This rate was lower than for control oocytes $(97.3 \%, \mathrm{P}<0.05)$. After $18 \mathrm{~h}$ IVM more oocytes $(\sim 80 \%, \mathrm{P}>0.05)$ were in MII with BLI than for control $(73 \%, \mathrm{P}<0.05)$. Shorter culture periods require lower BLI concentration for meiotic block; initial nuclear maturation kinetics of oocytes cultured with BLI is accelerated, and this is affected by culture period but not by drug concentration.
\end{abstract}

Keywords: bovine, meiosis, oocyte, butyrolactone I, kinetics, nuclear maturation

\section{RESUMO}

Estudou-se o efeito da concentração e do tempo de exposição à butirolactona I (BLI) no bloqueio meiótico e na cinética da maturação in vitro (MIV) de oócitos bovinos. No experimento 1, todos os oócitos encontravam-se em vesícula germinativa $(V G)$ após 6 h de cultivo nas concentrações de 0,50 e

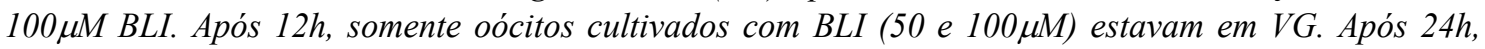
menos oócitos tratados com $50 \mu M(82 \%)$ estavam em $V G$ em relação a $100 \mu M(99 \%, P<0,05)$. No experimento 2, após $6 \mathrm{~h}$ de MIV, 93\% dos controles (somente MIV) estavam em VG, enquanto que nos tratados (100 $\mu$ M BLI por 6, 12 ou 24 h pré-MIV), menor proporção de oócitos permaneceu nesse estádio com o aumento do tempo de exposição à BLI antes da MIV (83 e 73\% para 6 e 12h, P<0,05). Com 24h de exposição, a taxa de VG foi similar à de $12 \mathrm{~h}$ (70\%, P>0,05). A taxa de metáfase II (MII, 76-81\%) foi similar para todos os tempos de exposição, após $18 \mathrm{~h}$ de MIV. No experimento 3, após $6 \mathrm{~h}$ de MIV, menos oócitos tratados (74\% para 50 ou $100 \mu \mathrm{M}$ BLI por 12h) estavam em VG comparados aos controles $(97 \%$, P<0,05). Após $18 \mathrm{~h}$ de MIV, mais oócitos estavam em MII com BLI ( 80\%, P>0,05) do que os controles (73\%, P<0.05). Conclui-se que para cultivos mais curtos, a concentração mais baixa de BLI bloqueia a

Recebido em 30 de novembro de 2004

Aceito em 13 de fevereiro de 2005

*Corresponding author (autor para correspondência)

E-mail: clvleal@usp.br

Apoio: FAPESP - processo 03/01479-6 
Effect of concentration...

meiose a cinética da maturação nuclear é acelerada em oócitos expostos à BLI e isso é afetado pelo tempo de cultivo, mas não pela concentração da droga.

Palavras-chave: bovino, meiose, oócito, butirolactona I, cinética, maturação nuclear

\section{INTRODUCTION}

In mammals, oogenesis begins during fetal life and oocytes remain in prophase I until a while before ovulation when they resume meiosis (oocyte maturation). This process is initiated with the activation of maturation promoting factor (MPF) leading the oocyte to progress from prophase I to metaphase II (MII). During MII, MPF remains at high levels maintaining the oocyte held in this stage until fertilization or parthenogenetic activation (Kubelka et al., 2000; Ledan et al., 2001).

It has been suggested that before meiosis resumption, oocytes undergo a process termed capacitation (Hyttel et al., 1997; Sirard, 2000) and that by removing oocytes from ovarian follicles for in vitro maturation (IVM) they would be precociously resuming meiosis and not undergoing capacitation, which would reduce developmental rates after in vitro fertilization (IVF) (Hyttel et al., 1997). An alternative to overcome this problem would be to maintain oocytes in meiotic block (prematuration culture) before submitting them to IVM.

Bovine oocytes have been successfully blocked in germinal vesicle (GV) stage using cyclin dependent kinase inhibitors (CDKIs), such as butyrolactone I (Kubelka et al., 2000, Hashimoto et al., 2002) and roscovitine (Mermillod et al.., 2000), by specifically blocking MPF activity. This, in turn, prevents resumption of meiosis maintaining oocytes arrested at germinal vesicle (GV) stage.

However, it has been observed that CDKIs may affect the kinetics of oocyte maturation after the prematuration culture (Hashimoto et al., 2002). To date, no studies have been conducted to evaluate the effects of different concentrations and culture period with CDKIs on the kinetics of oocyte nuclear maturation in vitro.

The present study aimed to evaluate the effects of concentration and exposure period of bovine oocytes to butyrolactone I, regarding meiosis inhibition and subsequent nuclear in vitro maturation.

\section{MATERIAL AND METHODS}

For the three experiments, oocytes were aspirated from $2-6 \mathrm{~mm}$ follicles of in slaughterhouse ovaries. Recovered oocytes presenting homogeneous cytoplasm and at least three layers of cumulus cells were selected for use. For blocking meiosis, oocytes were cultured in TCM-199 + 3mg/ml BSA, added with the inhibitor BLI (inhibition medium - IM) for 24h. For in vitro maturation (IVM, reversion of meiotic block), oocytes were cultured in TCM$199+10 \%$ FCS, $0.5 \mu \mathrm{g} / \mathrm{ml} \mathrm{FSH}, 5.0 \mu \mathrm{g} / \mathrm{ml} \mathrm{LH}$ and antibiotics (maturation medium - MM) for 6 , 12 or 18 hours to assess nuclear maturation kinetics. All cultures were in $100 \mu$ droplets $(20-$ 30 oocytes/droplet) of the appropriate medium under oil, at $38.5^{\circ} \mathrm{C}$, under $5 \% \mathrm{CO}_{2}$ in air.

To assess nuclear maturation stage, oocytes were stripped from their cumulus cells by vortexing for $5 \mathrm{~min}$ in $0.5 \mathrm{ml}$ saline solution $+5 \%$ FCS in a $1.5 \mathrm{ml}$ tube, fixed in ethanol: acetic acid (3:1) for $24 \mathrm{~h}$ and stained ( $2 \%$ acetic orcein). Oocytes were observed using a phase contrast microscope and were classified as the following: germinal vesicle stage (GV, immature oocytes); intermediate stages which included metaphase I (MI), anaphase I (AI), telophase I (TI); or metaphase II (MII, matured oocytes). Oocytes remaining in GV stage after inhibition were considered as completely blocked and oocytes in MII after IVM were considered to have fully reversed the meiotic block.

In experiment 1 , oocytes were cultured for 6,12 or 24 hours in inhibition medium with 0,50 or $100 \mu \mathrm{M}$ BLI. As a control, one group was cultured in the same medium in the absence of BLI. At the end of culture, oocytes were fixed and stained to determine the stage of meiosis. Those oocytes remaining in GV stage were considered blocked. 
In experiment 2, oocytes were cultured for 6,12 or 24 hours in IM added with $100 \mu \mathrm{M}$ BLI. After the inhibition period, oocytes were washed and cultured for another 6,12 and $18 \mathrm{~h}$ in MM, then, fixed and stained to determine meiotic stage in order to assess nuclear maturation kinetics. As controls, a group of oocytes was cultured and fixed after 6, 12 and 18h IVM.

In experiment 3, oocytes were cultured for 12 hours in IM containing 50 or $100 \mu \mathrm{M}$ BLI followed by in vitro maturation for 6,12 and $18 \mathrm{~h}$. Control oocytes were submitted only to IVM for the same culture periods. Oocytes were evaluated for nuclear maturation stage at the end of culture.
In all experiments, data from 4 replicates were analyzed by ANOVA and Duncan test was used at a $5 \%$ level of significance.

\section{RESULTS AND DISCUSSION}

In order to assess the effect of concentration and exposure period on induction of meiotic block, bovine oocytes were cultured in inhibiting medium containing different concentrations of butyrolactone I $(0,50$ and $100 \mu \mathrm{M})$ and cultured for different periods of time $(6,12$ and $24 \mathrm{~h})$, then evaluated for nuclear status (Table 1).

Table 1. Number of bovine oocytes in different nuclear maturation stages according to concentration and exposure period to BLI to induce meiotic block in vitro

\begin{tabular}{|c|c|c|c|c|c|}
\hline \multirow[t]{2}{*}{ BLI concentration } & \multirow[t]{2}{*}{ Exposure period } & \multirow{2}{*}{ Total oocytes } & GV & Intermediate & MII \\
\hline & & & $\mathrm{n}(\%)$ & $\mathrm{n}(\%)$ & $\mathrm{n}(\%)$ \\
\hline \multirow{4}{*}{$\begin{array}{l}0 \mu \mathrm{M} \\
\text { (Control) }\end{array}$} & $6 \mathrm{~h}$ & 64 & $64(100) \mathrm{a}$ & $0(0) \mathrm{c}$ & $0(0) \mathrm{c}$ \\
\hline & $12 \mathrm{~h}$ & 78 & $13(16.7) \mathrm{c}$ & $63(80.8) \mathrm{a}$ & $2(2.6) \mathrm{c}$ \\
\hline & $24 \mathrm{~h}$ & & & & $69(88.5) \mathrm{a}$ \\
\hline & & 78 & $1(1.3) \mathrm{d}$ & $8(10.2) b$ & \\
\hline \multirow{4}{*}{$50 \mu \mathrm{M}$} & $6 \mathrm{~h}$ & 66 & $66(100) \mathrm{a}$ & $0(0) \mathrm{c}$ & $0(0) \mathrm{c}$ \\
\hline & $12 \mathrm{~h}$ & 69 & $69(100) a$ & $0(0) \mathrm{c}$ & $0(0) \mathrm{c}$ \\
\hline & $24 \mathrm{~h}$ & & & & $14(18.4) b$ \\
\hline & & 76 & $62(81.6) \mathrm{b}$ & $0(0) \mathrm{c}$ & \\
\hline \multirow{3}{*}{$100 \mu \mathrm{M}$} & $6 \mathrm{~h}$ & 64 & $64(100) \mathrm{a}$ & $0(0) \mathrm{c}$ & $0(0) \mathrm{c}$ \\
\hline & $12 \mathrm{~h}$ & 63 & $63(100) \mathrm{a}$ & $0(0) \mathrm{c}$ & $0(0) \mathrm{c}$ \\
\hline & $24 \mathrm{~h}$ & 79 & $78(98.7) \mathrm{a}$ & $0(0) \mathrm{c}$ & $1(1.3) \mathrm{c}$ \\
\hline
\end{tabular}

BLI: butyrolactone I; GV: germinal vesicle, intermediate (metaphase I, anaphase I and telophase I);MII: metaphase II. Different letters in the same column indicate significant difference between treatments $(\mathrm{P}<0.05)$.

After a culture period of $6 \mathrm{~h}$, all oocytes (100\%) of all groups were still in GV stage, indicating that there was no effect of the inhibitor. When oocytes were exposed to BLI for a period of $12 \mathrm{~h}$, only oocytes cultured in the presence of the drug, irrespective of the concentration used, remained in GV stage $(100 \%)$. For the group of oocytes cultured in the absence of BLI (control), significantly less oocytes $(16.7 \%, \mathrm{P}<0.05)$ were still in GV. Correspondingly, most oocytes had already resumed meiosis and reached metaphase I stage $(80.8 \%)$. After a longer exposure period (24h), significantly more oocytes remained in $\mathrm{GV}$ in both inhibition groups than in the control group $(1.3 \%, \mathrm{P}<0.05)$, in which most of the oocytes reached metaphase II $(88.5 \%)$. However, a difference could be observed between different concentrations of the drug, in which the higher concentration $(100 \mu \mathrm{M})$ presented the highest $\mathrm{GV}$ rate $(98.7 \%, \mathrm{P}<0.05)$ when compared to the lower $(50 \mu \mathrm{M}, 81.6 \%)$. These results indicate that for shorter exposure times (up to 12h) efficient meiosis inhibition can be achieved using a lower concentration of the drug. On the other hand, for longer exposure times (up to 24h), a higher concentration is necessary to maintain efficient meiotic block.

These results confirm previous observations that there is a dose effect, in which higher concentrations of $\mathrm{CDK}$ inhibitors lead to increased GV rates (Lonergan et al., 2000; Kubelka et al., 2000; Imai et al., 2002; Ponderato et al., 2002). Even a mixture of two different CDK inhibitors (butyrolactone I and roscovitine) showed similar effects (Ponderato et al., 2002). 
Regarding the effect of exposure time to $\mathrm{CDK}$ inhibitors on meiotic block, there is no information available. Most reports use $24 \mathrm{~h}$ as the ideal inhibition period (Lonergan et al., 2000; Kubelka et al., 2000; Imai et al., 2002; Ponderato et al., 2002). Some groups have reported the effects of longer exposure times (40h) in which detrimental effects were observed in terms of structural alterations such as degeneration of cortical granules, organelle migration to the periphery of the oocyte and nucleolus fragmentation (Fair et al., 2002). Shorter exposure periods also led to slight changes in nuclear structures (Faerge et al., 2001). On the other hand, after a $24 \mathrm{~h}$ exposure, some changes were observed in granulosa cell integrity, morphological changes in mitochondria and also cortical granules degeneration (Lonergan et al., 2003). However, neither of these studies simultaneously compared different exposure periods, nor correlated these changes to effects on meiotic block or embryo development.
In a study carried out by Imai et al. (2002), a decrease in pronuclear formation, cleavage and blastocyst development after fertilization were observed after culturing bovine oocytes in the presence of $100 \mu \mathrm{M}$ for $48 \mathrm{~h}$. But, again, no effect on meiotic block was analyzed. In the present study, shorter culture periods were used, so it is believed that fewer changes would be occurring. However, further experiments are needed to verify whether shorter exposure periods and lower concentrations of CDK inhibitors could not be detrimental for embryo development, since it was evaluated only the efficiency for inducing meiotic block was evaluated.

The second experiment aimed to study the effect of exposure period to BLI on the kinetics of nuclear maturation. Oocytes were cultured in the presence of $100 \mu \mathrm{M}$ BLI for varying periods of time (6, 12 and 24h), then, in vitro matured. During IVM, oocytes were fixed at different time points $(6,12$ and $18 \mathrm{~h})$ to assess meiosis progression (Table 2).

Table 2. Number of bovine oocytes in different nuclear maturation stages along IVM according to previous exposure period to BLI $(100 \mu \mathrm{M})$

\begin{tabular}{lccccc}
\hline \hline Treatment & IVM period & Total oocytes & $\begin{array}{c}\mathrm{GV} \\
\mathrm{n}(\%)\end{array}$ & $\begin{array}{c}\text { Intermediate } \\
\mathrm{n}(\%)\end{array}$ & $\begin{array}{c}\text { MII } \\
\mathrm{n}(\%)\end{array}$ \\
\hline \hline \multirow{2}{*}{ Control } & $6 \mathrm{~h}$ & 70 & $65(92.9) \mathrm{a}$ & $5(7.1) \mathrm{a}$ & $0(0) \mathrm{c}$ \\
IVM & $12 \mathrm{~h}$ & 69 & $7(10.1) \mathrm{de}$ & $57(82.6) \mathrm{ab}$ & $5(7.2) \mathrm{c}$ \\
& $18 \mathrm{~h}$ & & & & $51(76.1) \mathrm{a}$ \\
& & 67 & $1(1.5) \mathrm{ef}$ & $15(22.4) \mathrm{ad}$ & \\
6h inhibition & $6 \mathrm{~h}$ & 81 & $67(82.7) \mathrm{b}$ & $14(17.3) \mathrm{de}$ & $0(0) \mathrm{c}$ \\
& $12 \mathrm{~h}$ & 74 & $12(16.2) \mathrm{d}$ & $58(78.4) \mathrm{ab}$ & $4(5.4) \mathrm{c}$ \\
& $18 \mathrm{~h}$ & & & & $60(75.9) \mathrm{a}$ \\
& $6 \mathrm{~h}$ & 79 & $1(1.3) \mathrm{ef}$ & $18(22.8) \mathrm{cd}$ & \\
12h inhibition & $12 \mathrm{~h}$ & 65 & $75(73.3) \mathrm{c}$ & $20(26.7) \mathrm{cd}$ & $0(0) \mathrm{c}$ \\
& $18 \mathrm{~h}$ & & $7(10.8) \mathrm{de}$ & $55(84.6) \mathrm{a}$ & $3(4.6) \mathrm{c}$ \\
& & & & & $47(77) \mathrm{a}$ \\
24h inhibition & 61 & $0(0) \mathrm{h}$ & $49(70) \mathrm{c}$ & $21(30.0) \mathrm{c}$ & $0(0) \mathrm{c}$ \\
& $12 \mathrm{~h}$ & 67 & $3(4.5) \mathrm{ef}$ & $49(73.1) \mathrm{b}$ & $15(22.4) \mathrm{b}$ \\
& $18 \mathrm{~h}$ & 67 & $1(1.5) \mathrm{ef}$ & $12(17.9) \mathrm{de}$ & $54(80.6) \mathrm{a}$ \\
\hline \hline
\end{tabular}

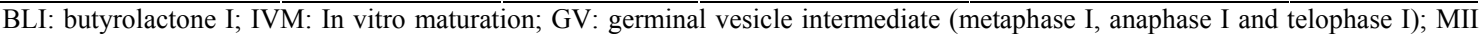
metaphase II.

Different letters in the same column indicate significant difference between treatments $(\mathrm{P}<0.05)$.

The data show that $92.9 \%$ of the control oocytes were still in $\mathrm{GV}$ after $6 \mathrm{~h}$ of maturation. When oocytes were cultured with BLI prior to IVM, significantly less oocytes were at this stage $(\mathrm{GV})$, after 6h IVM. When inhibition culture lasted 6h, $82.7 \%$ of the oocytes were in $\mathrm{GV}(\mathrm{P}<0.05)$ and a longer culture period induced an even lower number of oocytes in GV $(73.3 \%, \mathrm{P}<0.05)$. When inhibition lasted $24 \mathrm{~h}$, the results were similar to $12 \mathrm{~h}(70 \%, \mathrm{P}>0.05)$. After a maturation period of $12 \mathrm{~h}$, most $(82.6 \%)$ of the oocytes were in intermediate stages (metaphase I, anaphase I 
and telophase I) and the same was observed when oocytes were previously inhibited for $6 \mathrm{~h}$ and $12 \mathrm{~h}$ ( 78.4 and $84.6 \%$, respectively, $\mathrm{P}>0.05)$. After a $24 \mathrm{~h}$ inhibition, although the majority of oocytes were also found in intermediate stages $(73.1 \%)$, significantly more oocytes were already at metaphase II $(22.4 \%, \mathrm{P}<0.05)$ when compared to all other groups (4.6-7.2\%). When maturation proceeded up to $18 \mathrm{~h}$, all groups reached similar metaphase II rates $(75.9-80.6 \%, \mathrm{P}<0.05)$.

The inhibition treatment induces an acceleration of the initial steps of meiosis progression and that this acceleration is affected by the period of time the oocytes are exposed to BLI prior to maturation. However, as maturation progresses this effect is less evident since maturation rates are similar for all groups after $18 \mathrm{~h}$ maturation.

Studies have also observed that there is acceleration in nuclear maturation kinetics. Ponderato et al. (2001) and Hashimoto et al. (2002) observed that there was acceleration in meiosis resumption and progression of about 4 and $5.5 \mathrm{~h}$, respectively. After $20 \mathrm{~h}$ maturation, however, the differences were no longer observed. Using a different CDK inhibitor (roscovitine), similar observations were made in bovine (Lagutina et al., 2002) and pig oocytes (Marchal et al., 2001). In pig oocytes, a greater acceleration in maturation kinetics was observed when the culture period with the inhibitor was longer. These results are similar to those of the present study, in which the exposure period correspondingly increases the speed of nuclear progression. The differences are no longer observed later, during meiotic maturation (after $18 \mathrm{~h}$ in this study). The reasons for this acceleration are still unclear, but it has been suggested that during the inhibition culture, the oocytes would have started the synthesis of components important for the development and that some degree of meiotic progression might occur during inhibition (Ponderato et al., 2001).

The experiment 3 aimed to evaluate the effect of BLI concentration $(50$ and $100 \mu \mathrm{M})$ on the nuclear maturation kinetics of oocytes exposed to BLI for $12 \mathrm{~h}$. During maturation, oocytes were fixed at 6,12 and $18 \mathrm{~h}$ to assess nuclear status.

Table 3. Number of bovine oocytes in different nuclear maturation stages along IVM according to BLI concentration after a previous $12 \mathrm{~h}$ meiosis block

\begin{tabular}{|c|c|c|c|c|c|}
\hline Treatment & IVM period & Total oocytes & $\begin{array}{c}\mathrm{GV} \\
\mathrm{n}(\%)\end{array}$ & $\begin{array}{c}\text { Intermediate } \\
\mathrm{n}(\%)\end{array}$ & $\begin{array}{c}\text { MII } \\
\mathrm{n}(\%)\end{array}$ \\
\hline \multirow{4}{*}{$\begin{array}{l}\text { Control } \\
\text { IVM }\end{array}$} & $6 \mathrm{~h}$ & 73 & $71(97.3) \mathrm{a}$ & $2(2.7) \mathrm{e}$ & $0(0) \mathrm{e}$ \\
\hline & $12 \mathrm{~h}$ & 77 & $9(11.7) \mathrm{c}$ & $60(77.9) \mathrm{b}$ & $8(10.4) d$ \\
\hline & $18 \mathrm{~h}$ & & $2(2.7) \mathrm{d}$ & $18(24.3) \mathrm{cd}$ & $54(72.9) \mathrm{b}$ \\
\hline & & 74 & & & \\
\hline \multirow{4}{*}{$50 \mu \mathrm{M}$ BLI } & $6 \mathrm{~h}$ & 70 & $52(74.3) b$ & $18(25.7) \mathrm{c}$ & $0(0) \mathrm{e}$ \\
\hline & $12 \mathrm{~h}$ & 66 & $3(4.5) \mathrm{d}$ & $51(77.3) \mathrm{b}$ & $12(18.2) \mathrm{d}$ \\
\hline & $18 \mathrm{~h}$ & & $1(1.4) d$ & $13(18.1) \mathrm{d}$ & $58(80.5) \mathrm{a}$ \\
\hline & & 72 & & & \\
\hline \multirow{3}{*}{$100 \mu \mathrm{M}$ BLI } & $6 \mathrm{~h}$ & 74 & $55(74.3) \mathrm{b}$ & $19(25.7) \mathrm{cd}$ & $0(0) \mathrm{e}$ \\
\hline & $12 \mathrm{~h}$ & 81 & $3(3.7) \mathrm{d}$ & $70(86.4) \mathrm{a}$ & $8(9.9) \mathrm{d}$ \\
\hline & $18 \mathrm{~h}$ & 95 & $1(1.1) \mathrm{d}$ & $19(20) \mathrm{cd}$ & 75 (78.9) a \\
\hline
\end{tabular}

BLI:butyrolactone I; IVM: in vitro maturation; GV: germianl vesicle, intermediate (metaphase I, anaphase I and telophase I);MII: metaphase II.

Different letters in the same column indicate significant difference between treatments $(\mathrm{P}<0.05)$

After a $6 \mathrm{~h}$ maturation period, $97.3 \%$ of the oocytes were in GV. When oocytes were cultured for $12 \mathrm{~h}$ in the presence of 50 or $100 \mu \mathrm{M}$ BLI, prior to maturation, significantly less oocytes remained in GV $(74.3 \%$ for both groups $\mathrm{P}<0.05)$. After IVM for $12 \mathrm{~h}$, most control oocytes $(77.9 \%)$ were in intermediate stages of meiosis as oocytes cultured with $50 \mu \mathrm{M}(77.3 \%$, $\mathrm{P}>0.05)$. Oocytes cultured with $100 \mu \mathrm{M}$ were also mostly at intermediate stages of meiosis, however, at higher rates than the other two groups $(86.4 \%, \mathrm{P}<0.05)$. After $18 \mathrm{~h}$ of IVM, however, significantly more oocytes were in metaphase II in both inhibitor groups (80.5 and 
$78.9 \%$, for 50 and $100 \mu \mathrm{M}$, respectively) than in the control group $(72.9 \%, \mathrm{P}<0.05)$. These results suggest that a culture period of $12 \mathrm{~h}$ in the presence of BLI is enough to induce acceleration of nuclear maturation, irrespective of the used concentration.

These results confirm that BLI treatment accelerated nuclear maturation, even using a shorter culture period (12h) and that this acceleration is mostly non-dependent on the concentration used. There are no studies on the effect of drug concentration on maturation kinetics, but it can be suggested that CDK inhibitors used for short periods, even at low concentration, could be able to induce changes to the oocyte, which seem to be related to cell cycle control molecules. These drugs are known to specifically inhibit MPF and also indirectly MAPK (Kubelka et al., 2000), which are important regulatory proteins controlling the cell cycle. However, it cannot be ruled out that these drugs also affect other molecules important for cell cycle control. Further experiments are needed to clarify this point.

\section{CONCLUSIONS}

The efficiency of meiotic block is affected by the concentration and the period of time oocytes are exposed to BLI. Longer times need higher concentrations to be effective in blocking meiosis. Nuclear maturation kinetics is mainly affected by BLI exposition time, and this acceleration is mostly observed during the initial steps of maturation. Additional studies are necessary to verify the effects of concentration and culture period on the developmental capacity of these oocytes.

\section{REFERENCES}

FAERGE, I.; MAYES, M.; HYTTEL, P. et al. Nuclear ultrastructure in bovine oocytes after inhibition of meiosis by chemical and biological inhibitors. Mol. Reprod. Dev., v. 59 , p.459-467, 2001.

FAIR, T.; HYTTEL, P.; MOTLIK, J. et al. Maintenance of meiotic arrest in bovine oocytes in vitro using butyrolactone I: effects on oocyte ultrastructure and nucleolus function. Mol. Reprod. Dev., v.62, p.375-386, 2002.

HASHIMOTO, S.; MINAMI, N.; TAKAKURA, R. et al.
Bovine immature oocytes acquire developmental competence during meiotic arrest in vitro. Biol. Reprod., v.66, p.1696-1701, 2002.

HYTTEL. P.; FAIR. T.; CALLESEN, H. et al. Oocyte growth capacitation and final maturation in cattle. Theriogenology, v.47, p.23-32, 1997.

IMAI, K.; KOBAYASHI, S.; KANEYAMA, K. et al. Effects of butyrolactone I on GVBD in bovine oocytes and subsequent maturation, fertilization and development in vitro. J. Reprod. Dev., v.48, p.249-255, 2002.

KUBELKA, M.; MOTLIK, J.; SCHULTZ, R.M. et al. Butyrolactone I reversibly inhibits meiotic maturation of bovine oocytes, without influencing chromosome condensation activity. Biol. Reprod., v.62, p.292-302, 2000 .

LAGUTINA, I.; PONDERATO, N.; LAZZARI, G. et al. Kinetics of oocyte maturation and subsequent development of IVF, parthenogenetic, and NT bovine embryos after meiotic inhibition with roscovitine. Cloning Stem, v.4, p.113-119, 2002.

LEDAN, E.; POLANSKI, Z.; TERRET, M.E. et al. Meiotic maturation of the mouse oocyte requires an equilibrium between cyclin B synthesis and degradation. Dev. Biol., v.232, p.400-413, 2001.

LONERGAN, P.; DINNYÉS, A.; FAIR, T. et al. Bovine oocyte and embryo development following meiotic inhibition with butyrolactone I. Mol. Reprod. Dev., v.57, p.204-209, 2000.

LONERGAN, P.; FAERGE, I.; HYYTEL, P.M. et al. Ultrastructural modifications in bovine oocytes maintained in meiotic arrest in vitro using roscovitine or butyrolactone. Mol. Reprod. Dev., v.64, p.369-378, 2003.

MARCHAL, R.; TOMANEK, M.; TERQUI, M. et al. Effects of cell cycle dependent kinase inhibitor on nuclear and cytoplasmic maturation of porcine oocytes. Mol. Reprod. Dev., v.60, p.65-73, 2001.

MERMILLOD, P.; TOMANEK, M.; MARCHAL, R. et al. High developmental competence of cattle oocytes maintained at the germinal vesicle stage for 24 hours in culture by specific inhibition of MPF kinase activity. Mol. Reprod. Dev., v.55, p.89-95, 2000.

PONDERATO, N.; CROTTI, G.; TURINI, P. et al. Embryonic and foetal development of bovine oocytes treated with a combination of butyrolactone I and roscovitine in an enriched medium prior to IVM and IVF. Mol. Reprod. Dev., v.62, p.513-518, 2002.

PONDERATO, N.; LAGUTINA, I.; CROTTI, G. et al. Bovine oocytes treated prior to in vitro maturation with a combination of butyrolactone I and roscovitine at low doses maintain a normal developmental capacity. Mol. Reprod. Dev., v. 60, p.579-585, 2001.

SIRARD, M.A. Resumption of meiosis: mechanism involved in meiotic progression and its relation with developmental competence. Theriogenology, v.55, p.1241-1254, 2000. 